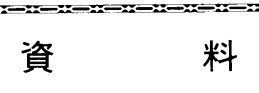

\title{
CRT ディスプレイ
}

\section{大沢通孝*}

\section{1.はじめに}

本章ではブラウン管 (CRT) を用いた直視型及び投写型 ディスプレイの最近の動向, 進歩について述べる.

直視型ディスプレイについては, 前回の報告書に紹介さ れた16：9のワイドアスペクトCRTは，本来はハイビジ ヨン用に開発されたものであったが, 現行放送用をワイド で見る機能を搭載し, 走查線数も現行放送と同一仕様とす るなどして，セット価格を大幅に低下させたことで急速に 普及しつつある。それに伴い，開発当初は32型，36型のみ であった CRT サイズは, 普及の中心となっている28型, 24 型に加えて16型も製品化されている. 性能的にも，マスク ピッチなどの最適化を図ることで, 現行 $4: 3$ のアスペク トCRTに対して遜色がないほどに高輝度化・ハイコント ラスト化が図られている。

一方, 現行 $4: 3$ の CRT は不況やワイドテレビの普及 などの影響で，29型を中心とした大型の伸びが大幅に低下 し，21，25型を中心とした中型や小型機種が伸びた．中 · 小型機種は生産を海外に求め, 大幅に低価格化を図った。

一方, 長年研究されてきた完全フラット CRT も，14型サ イズの現行放送对応で製品化され話題を集めた。

コンピュータ端末用の高精細データディスプレイは，ワ 一クステーションやパソコンの上位機種用など 20 型 $1 \mathrm{M} ヒ ゚$ クセル表示から 21 型フラットフェースの2M ピクセル表示 に移行しつつある。これらは, マイコンで制御されたマル チスキャン対応となっており, 多くの種類の入力信号に対 応できる。一方, 数量的には 14,15 型が今だに多いものの, 17型の伸びが急速であり, 液晶ディスプレイ（LCD）の普 及も考之ると, 近い将来, パソコン用の CRT モニターの中 心は17型に置き換わるものと予想される.

投写型ディスプレイは北米市場での伸びは順調である が，国内での伸びは不況の影響もあり，ここ数年期待でき なかった。しかし，技術的に興味をひく開発がいくつかな されており, ワイドテレビの市場の伸びに伴い，投写型テ レビの普及の兆しも現われ始めている.

ここでは，最近の技術を中心に，発表された文献をもと に具体的に紹介する。

\footnotetext{
*侏立製作所研究開発推進本部
}

紹介者：小原 章男

\section{2. 直視型ディスプレイ}

画面アスペクト化が $4 ： 3$ の現行放送対応ディスプレイ における大きな技術的トピックは，広角偏向化であろう。 これはフラットフェース化同様, 周辺フォーカスの劣化を 招くため, 電子銃, 偏向ヨークの改良が精力的になされて いる。

フラットフェース化は，1986年以降顕著になった大型化 と並行して進められた。フラット化はバルブ強度の確保は むろんのこと, シャドウマスクのドーミング（電子ビーム 照射による温度上昇でマスク形状が変形すること. 結果と して電子ビームが決められた蛍光体を照射できず，色純度 の劣化をもたらす)対策, 映り込み像の自然さ, 画像歪(ク ロスハッチ表示など顕著）など多くの課題と取り組みなが ら改良されてきた。最近のものは, 画面周辺(ペリフェリ) の曲率が平均で $4.2 \mathrm{~m}$ 程度になっており,フラット性が高め られている。图 1 にパネル表面形状の例を示す ${ }^{11}$.

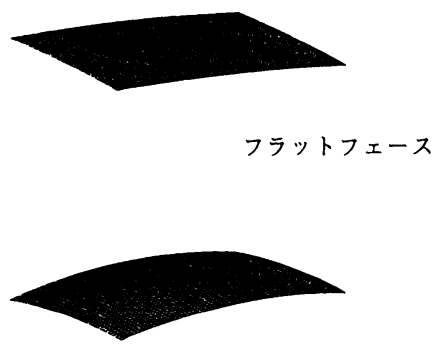

従来形状

図 1 パネル表面形状

広角偏向化は CRT の全長短縮を狙い, セット側での改 善とともに，29型セットで家具の標準的な奥行き $45 \mathrm{~cm}$ 実 現した12). フォーカス, ミスコンバーゼンス (赤, 緑, 青 が蛍光面上で一点に集中しないことによって生ずる色ず れ), 画像歪などの表示特性, 偏向回路の消費電力, および 価格に影響するネック径は, $29.1 \mathrm{~mm}, 32.5 \mathrm{~mm}$ などで製品 化されている. $37.5 \mathrm{~mm}$ ネック径の CRT は, 一部データデ イスプレイや業務用で使われている.

大画面化, 高輝度化, 高コントラスト化（フェースプレ 一トの光透過率低減) の流れでビーム電流は增加の一途を たどり，スポット径は大きくなる傾向にある，そこに，広 角偏向化も加わり, 周辺フォーカス特性は一層厳しい状況 
である。これに対し，電子銃と偏向ヨークの改良で従来以 上の性能を実現している。電子銃の改良は基本的に電子レ ンズの口径拡大, 具体的にはオーバーラップ構造の開発・ 展開により, 等価的な大口径を実現できる構造が実現でき 性能向上が図られている. 図 2 に電子銃の 1 例を示す ${ }^{3)}$. 主 レンズは $\mathrm{G} 5$ 電極と $\mathrm{G} 6$ 電極の開口部で形成される。主レ ンズは， 3 本のビームに対応した 3 個の楕円開口と, 共通 に作用する横長の大口径開口の組み合わせで構成され $3^{13)}$. 図 3 で $G 5$ 電極が 2 分割されているのは, 走査に応 じてビームの縦・横の比率を変え, 非点収差補正を行なわ せたり，レンズの焦点距離を変えたりする機能をもたせて いるためである。このダイナミック補正を行う電圧の低減 が重要な技術課題で，いくつかの有益な提案がなされてい $3^{344)}$. 一方，多イナミックフォーカス電圧発生回路でも図 3 の示すように, 帰線期間に発生する不要電圧を除圧する と同時に，回路を簡略にするなどの改良を加之た提案がな されている5.

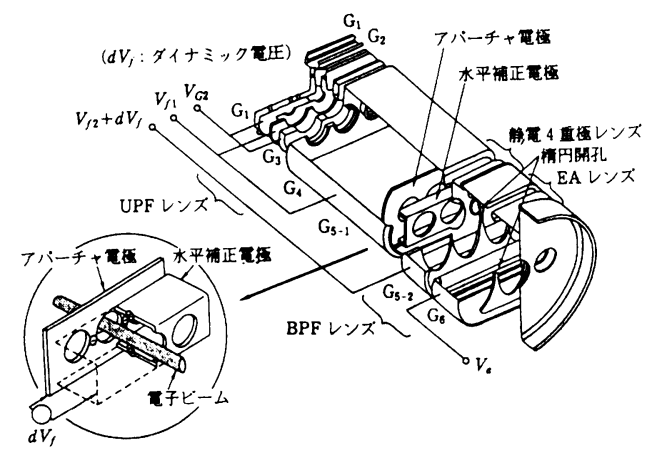

目 2 電子銃構造

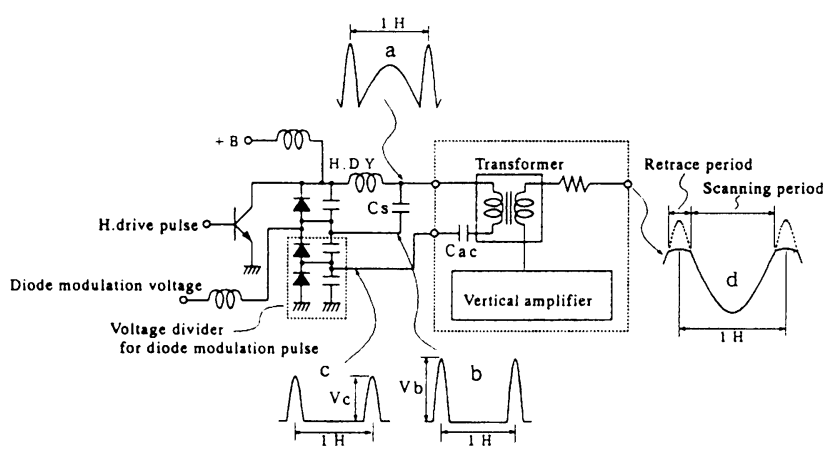

図3簡易型タイイミックフォーカス回路

偏向角という観点からみたワイド CRT は，八イビジョ ン CRT の仕様を日本電子機械工業会（EIAJ）で決めた当 時の106度となっている. 大画面でより効果があるワイド CRT では，大型化に伴う奥行きの問題は一層重要である が, 周辺フォーカスとの両立も技術的に大きな課題である.

データディスプレイ用 CRT の偏向角は, 表示画面全体 のフォーカス品質が均一であること，すなわちスポット径 の絶対值のみならず真円度, さらには画像歪特性も強く要 求されるため 90 度偏向である。しかし，LCD な゙゙の普及と ともに奥行きの問題はさらにクローズアップされ，広角偏 向化の要求はますます強まるであろう.
データディスプレイでは，利用者がセットに接近して長 時間使うため, 漏洩磁界644)や漏洩電界819)の規制（例之ば， スエーデン王立計量試験評議会 SWEDACの測定勧告な どに準拠したもの）が非常に厳しい。これらの規格はセッ トから一定の距離での磁界, および電界の強さを規定した ものである。人体と磁界・電界の関連性はまだ十分には解 明されていないが, 安全性の問題でもあり, 市販されてい るデータディスプレイの多くはこの規格を満足している.

データディスプレイで特に重視されるのが, CRT 表面の 外光反射がある。視覚障害の原因となる可能性もあり, 従 来から「ノングレア」処理，「低反射」コートなどがなされ てきた。しかし，前者は低価格ではあるが，解像度，コン トラストなどを低下させ，後者は薄膜を多層化する必要が あり高価格であった。これに対し，最近，価格と性能の両 立が可能な 2 つの方式か開発された。 1 つは, 図 $4{ }^{10)}$ に示す ように，ノングレア処理に用いられるシリカコート（反射 像をぼかす）と， 2 層コート（低反射導電層）を組み合わ せた 3 層コートで10), もう 1 つ方法は, 単粒子配列された $\mathrm{SiO}_{2}$ 超微粒子による低反射膜と, 導電性を有する $\mathrm{SnO}_{2}$ 超 微粒子による带電防止膜の 2 層膜で構成されたものであ る ${ }^{11}$.これらは, 嚴密な光学的特性は多層膜コ一トには及ば ないものの，実用的には十分な特性を実現しており，低価 格，シールド効果など多くのメリットを有している．現状 のシリカコートによるノングレア処理のみのセットや，価 格の高い多層膜コートのセットなどが，これらの技術を用 いたセットに順次置き換えられていくだけでなく，一般テ レビセットにも採用されていくであろう。

完全フラットの CRT は長年研究された成果が実り, 1993年に14型の大きさで現行放送対応テレビ受像機として 製品化され，21型プラズマディスプレイとともに話題を呼 んだが広く普及するまでには至っていない。

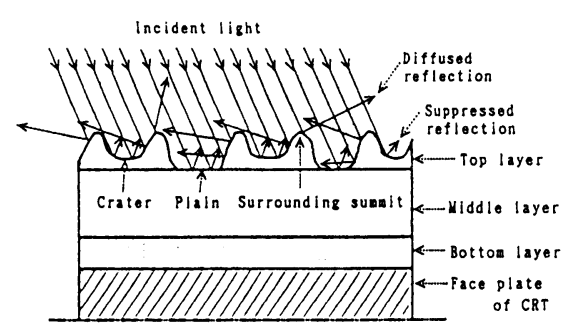

図 4 ノングレア，低反射帯軋防止コートの構造

\section{3. 投写型ディスプレイ}

CRT 投写型ディスプレイは, CRT, 投写レンズ，スクリ ーンなどで構成される，家庭用としては，明るい室内でも 良好な画像が保てる背面投写型が主流で，画面サイズは 40 型 (北米では50型) 前後が一般的である。CRT サイズは 5 型なども開発されたが，現在の主流は 7 型である。ここ数 年における市場の動きとしては，北米市場が伸びており年 間40万台以上の需要があるのに対し，国内は LCDの投写 型を含好も年間 7 万台程度で低迷している。しかし，最 
近はテレビのワイド化にともない，大画面化とコンパクト 化の両立が直視方式に比べ有利な投写型が見直され始めて いる.そのため, 最近の傾向としてはセットサイズのコン パクト化，特に奥行き短縮が大きな流れとなっている．奥 行き短縮には，図 5 の光学系ブロック図 ${ }^{13)}$ から明らかなよ うに，スクリーンのカラーシフトの低減などが, 電気系で は，CRT および投写レンズの集中角の増加による歪，コン バーゼンス補正能力の增強が必須となる。

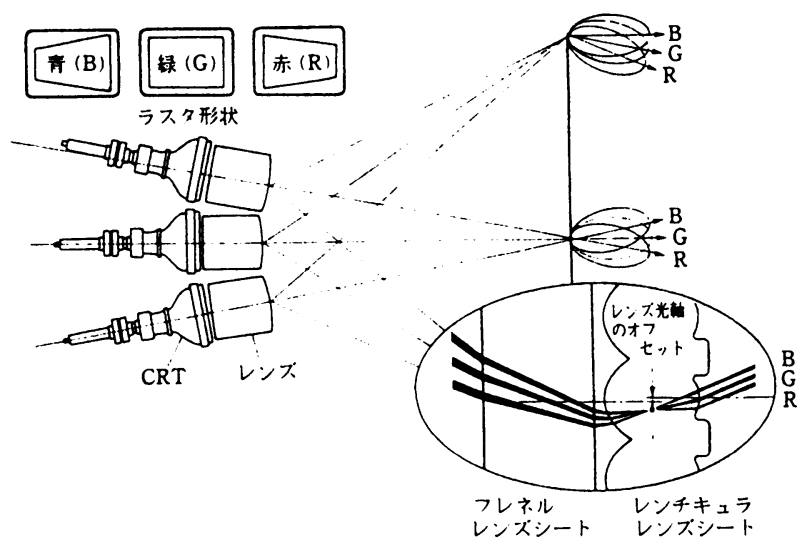

図 5 投写光学系

光学系における技術動向としては，投写レンズのハイブ リッド化（球面ガラスと非球面プラスチックレンズ）が急 速に進んだ。これは，投写距離が短くなるにつれてレンズ の収差補正が大きくなり, 球面のガラスレンズでは実用上 対応できないためである，環境変化（温度や湿度）に弱い プラスチックレンズが，八イビジョン用のレンズとして使 われ始めた背景には，設計・製造と補償技術が確立された ためである14115). 図 6 にレンズ構造・仕様の1例を示す15).

投写レンズ同様，スクリーンも改良されている。四 5 の ように，集中角が大きくなるにつれ，投写光の色による経 路の違いが大きくなる。これは見る位置により，色のバラ ンスが崩れるカラーシフトを発生させる。これを改善する ために，レンチキュラーレンズ（円筒レンズ）の形状を楕 円から非球面化している ${ }^{16)}$. 一方，フォーカス，コントラス トなどの画質向上に関する改造も，スクリーンでなされて いる.具体的には図 $7^{177}$ に示すように, スクリーンシートの 薄板化, 拡散材の出射側表面配置（従来はスクリーン内部 に分散）であり, シートの着色, さらに入射面, 出射面へ の反射防止コーティングなどである。

投写距離の短縮を中心に上記の技術を開発・導入し，39 型の画面サイズで14型相当の奥行き（39cm）で実現したセ ットも製品化された ${ }^{16)}$.

投写管における技術開発では, 蛍光膜の薄膜化と電子銃 の改良などが大きい。

蛍光膜の薄膜化は, 蛍光膜内部での光の散乱を低減しス ポット径の拡大を抑之る効果がある。この技術の実用化に より, 従来, 低カソード電流領域で電流の減少とともにス ポット径が減少しない, という飽和傾向が大幅に改善され,
電子銃の性能がより直接的にみられるようになった。この 様子を図 $8^{18)}$ に示寸. 反面, 単に膜厚を薄くするとピンホー ルの発生や輝度の低下が生じる。これに対しては, 蛍光体 を高密度に充填することで解決している。

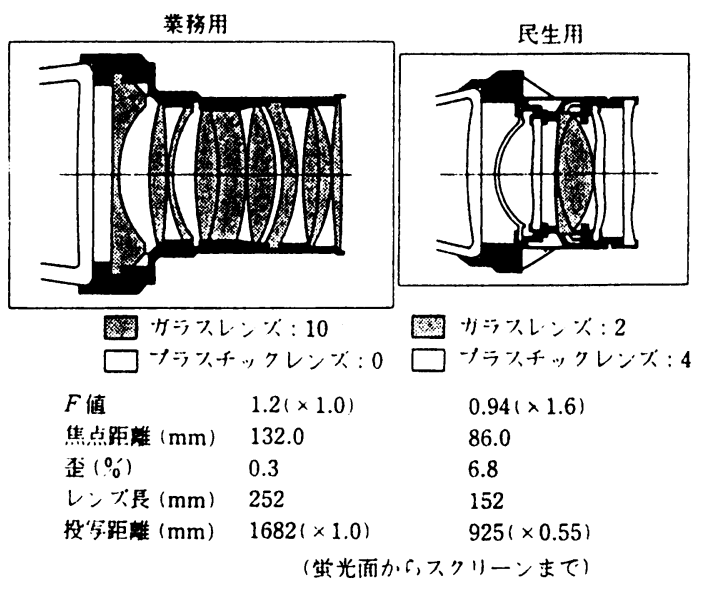

図 6 投写レンズ

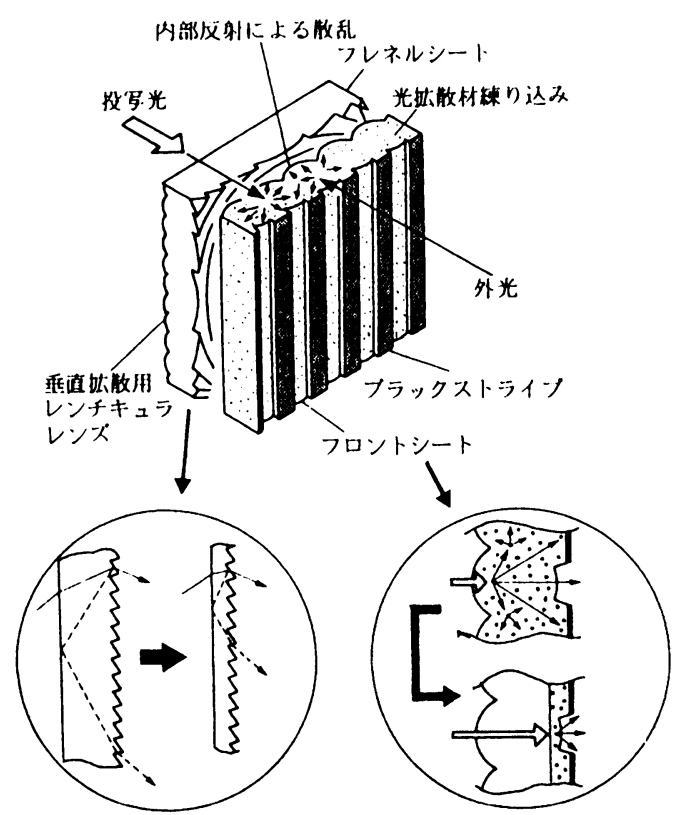

図 7 スクリーン構造
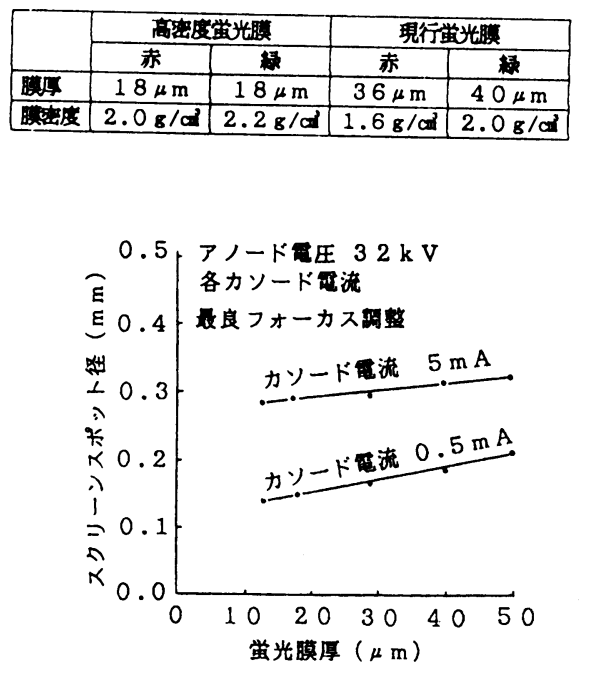

図 8 蛍光体膜厚とスポット径 
投写管の電子銃には，静電レンズによる静電集束方式と 電磁レンズによる電磁集束とがある，現在量産されている 方式は, 静電集束方式および, 電磁レンズを主レンズとし 静電レンズを補助レンズとした複合集束方式の 2 つであ る。最近では，価格が安く取扱が簡単でコンパクトにでき る静電集束方式が主流となりつつある。単ビームである投 写管に扔いても，等価的なレンズ口径の大型化を困ること で集束能力を改善している。投写管のネック径は $29.1 \mathrm{~mm}$ が一般的であるが，八イビジョン用や業務用などは，さら に物理的なレンズ口径の拡大も図るために，36.5mm を採 用するものもある。

一方，価格，取扱， CRT 全長などの点で不利な複合集束 方式も，カソード電流の全領域でシャープなフォーカス特 性が実現できるため，業務用のみならず一般民生用でも多 く使われている。複合集束方式における改善点は, 補助レ ンズである静電レンズの改良 ${ }^{18)}$ と主レンズ自身の改良とシ ステム全体の改良がある．主レンズ自身の改良は，集束磁 界の均一化と集束磁石の低損失化などがある。低損失化は, 水平偏向周波数が高いデー夕表示用の投写形ディスプレイ 用においては重要な課題である。これを解決するため，磁 石を金属からプラスチック化する試みなどもなされてい る ${ }^{19)}$.これにより, 水平多イナミックフォーカスの磁界損失 が大幅に軽減される。サマリウムコバルトなどの粉末を， バインダーで成型したプラスチック磁石は, 導電率・透磁 率が小さく高周波における損失が小さく，形状設計が自由 などの利点を有する。この性質を利用して, コンバーゼン スヨーク (CY) などを含めたトータルシステムで，フォー カス改善の試みもなされている20). 集束磁石のヨークの一 部を $\mathrm{CY}$ としても使い本来の $\mathrm{CY}$ を除去し，集束磁石を蛍 光面に近づけることでレンズ倍率の低減を図り, 集束能力 を高めたものである.CRT の構造を図 $9^{20}$ に示す.また， CY 機能を備えた集束磁石の構造を図1020に示す。この方 式によるレンズ倍率の低減で蛍光面中央のビーム径は $20 \%$ 改善年されている.また, 周辺部は低倍率化により一般には スポット形状は歪を受けやすくなるが, 偏向磁界 (DY, CY とも）の均一化により解決している.

投写管に用いられる蛍光体は，入射電力が非常に大きな 領域で使われているために, 高電流領域で輝度の飽和が生 ずる。これは，青蛍光体が最も顕著で，関係者の努力にも かかわらず適当な材料がなかなか見つからないのが現状で ある。しかしながら，偏向周波数の増加にともない電流飽 和の傾向は緩和され, 光出力は図1 $11^{15) 211}$ に示す様に増加す るため, 八イビジョンやデータディスプレイ用では有利に 作用する。赤, 緑, 青の蛍光体の発光特性の違いを回路で 補正し, 色温度の管理をより撖密に行う努力も一部ではな されている13).

投写型ディスプレイと直視型ディスプレイにおいて，回 路構成上最も大きな違いはコンバーゼンス補正回路であ る。直視型ではごく一部の業務用を除いて，コンバーゼン 又補正は偏向ヨーク（DY）とCRT で行っている（もっと
も，最近では簡単な回路が DY に搭載されはじめたが，回 路規模, 補正能力がまったく異なる)。コンバーゼンス補正 回路は，方式によりアナログとデジタル，およびそれらを 組み合わせたハイブリッド方式がある，民生用はアナログ 方式が主流であるが，すべてデジタルで処理する方式も開 発22)され，最近では，マルチモード用に対応できるシステ ム ${ }^{23)}$ に発展している。経時変化, 設置場所による色ずれなど

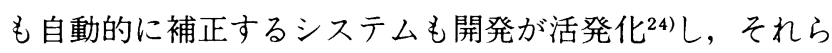
の一部は民生用として実用化 ${ }^{25}$ されている。

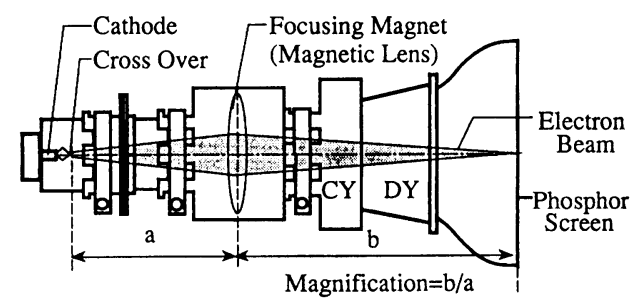

図 9 投写管の構造

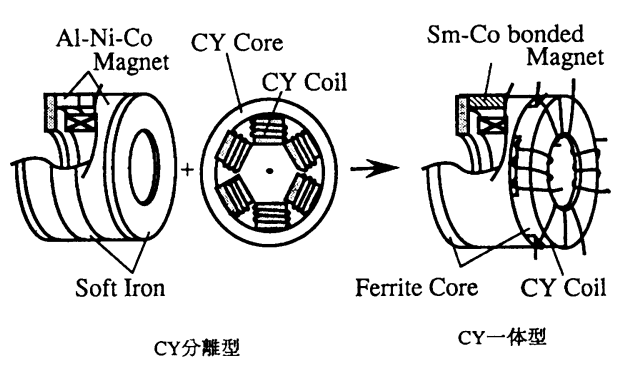

図10 CY 一体集束磁石

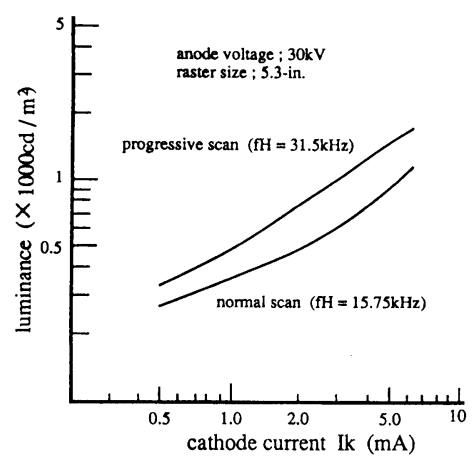

図11学光体の光出力特性

\section{4. その他の CRT ディスプレイ}

CRT をランプ代わりに用いる大画面ディスプレイ用 CRT も, 輝度, 発光効率, 寿命特性の向上扔よび低価格化 を図るべく, 蛍光化の塗布, CRT 構造などを中心に開発が 進んでいる。フェースプレートの蛍光体叙布面を平坦化す ることにより印刷法を適用し，蛍光面を平坦かつ高密度充 填することにより, 輝度, 寿命などを大幅に改善した報告 ${ }^{25)}$ がなされている。 


\section{5.まと め}

LCD, PDP など CRT を追いあげるデバイスの性能向上 が進み, CRT も守りにはいらざるをえない。しかし, CRT は画質, 精細度, 価格などバランスがとれており, しばら くはディスプレイデバイスの主役と思われるが, 重量, 奥 行きなど本質的な問題もあり, それぞれのデバイスの特徵 を活かしてお互いにさらに発展していくものと思われる.

\section{参 考 文 献}

(1) 細谷他：大型短全長カラーブラウン管の開発, テレビ学技報 IDY'93-164, Vol.17, No.71, pp.13-18 (Nov.1993)

(2) 山中他：奥行き短縮大か型カラーブラウン管の開発, テレビ学 技報 IDY'93-164, Vol.17, No.71, pp.25-30（Nov.1993）

(3) 白井他：EA-DF 電子銃のダイナミック電圧低減, IDY'91-151, Vol.15, No.72, pp.27-32 (Nov.1991)

(4) 富永他：HDTV カラー CRT 用高性能電子重, テレビ学技報 IDY'93-11, Vol.17, No.1, pp.61-66 (Jan.1993)

（5）塚原他：EA-DF 電子銃用簡易型ダイナミックフォーカス回 路, テレビ学技報 IDY'93-165, VOl.17, No.71, pp.19-24 (Nov.1993)

（6）田上他：14 “カラーディスプレイ CRT 用低漏洩磁界 SS 偏向 ヨーク, テレビ学技報, EDI’91-100, Vol.91, No.407, pp.31. 35 (Jan. 1992)

(7) 奥山他： $48 \mathrm{~cm}$ カラーディスプレイ用高機能偏向ヨーク, テレビ 学技報, IDY 92-116, VO1.16, No.48, pp.39-43 (July 1992)

(8) R. D. Capples: 9.1 "Cancellation of ELF/ VLF Electric Fields from CRT Displays”, SID '92 Technical Report, SESSION 9: DISPLY SYSTEMS (1992)

（9）木藤, 大沢 : 低電界不要輻射水平偏向回路の検討, テレビ全大' 93, ITEC'93, 1-3, pp.5-6 (1993)

(10) 有元他：CRT 用ノングレア, 低反射, 带電防止 (AGRAS) コ 一ト，テレビ学技報，IDY92-78, pp.11-16 (1992-12)

(11) 遠藤他：超微粒子による低反射带電防止膜, テレビ学技報, IDY94-3, Vol.18, No.2, pp.13-16 (Jan.1994)

(12) K. Yamamoto, M. Yokomakura, S. Inohara, K. Nonomura: A 14-in. Color Flat-Panel Display Using Filament Cathodes, 25.1, pp.381-384, SID 94 DIGEST

(13) 大沢他：2. 投写型テレビの色再現, テレビ誌, Vol.7, No.8,

pp.1100-1102 (1993)

(14) 平田他：投写型 HD ディスプレイ用ハイブリッド投写レンズ の設計, 応物分科会日本光学会第16回光学シンポジウム資料 (June, 1991)

(15) 大沢, 大木, 窪田, 武永 : 7-4 HD ディスプレイ, テレビ誌, Vol.45, No.11, pp.1403-1407 (1991)

(16) 吉田他：CRT 投写型ディスプレイ用超短投写光学系の開発, テレビ学技報 IDY 94-82, Vol.18, No.34, pp.61-66 (19946)

(17) 大沢他：3-1 CRT 投写型ディスプレイ, テレビ誌, VO1.47, No.7, pp.936-940 (1993)

(18) 広田他：HDTV 用 $16 \mathrm{~cm}$ 高解像度投写形ブラウン管, テレビ学 技報 IDY 93-12, Vol.17, No.1, pp.67-72（Jan.1993）

(19) 大高他：電磁集束方式投写形ブラウン管の集束マグネットへ のプラスチックマグネットの適用, テレビ学技報, IDY 92-115, Vol.16, No.98,pp.33-38 (1992 7月)

(20) 大高他：投写形ブラウン管の CY 一体型電磁集束システム, テ レビ全大，6-10,pp.103-104, ITEC'93 (1993)

(21) M. Ohsawa et. al: 46-in. High-Resolution Rear-Projection Display, J. of SID, Vol.1, No.1, 1993

(22) M. Ohsawa et. al.: A High-Resolution Rear Projection TV for Home-Use, IEEE Trans. Consum. Electron., Vol.35, No.3, pp.325-333 (Aug. 1989)

(23) 野口他：2 モード対応ディジタルコンバーゼンスシステムの 開発，テレビ全大 6-11, pp.105-106, ITEC'93 (1993)

(24) 田中英夫：リアプロジェクタにおける静コンバーゼンス補正 システム, テレビ全大 5-6, pp.111-112, ITEC'92 (1992)

(25) 侏)日立製作所カタログ，電波新聞（1994.4.26および5.2）

(26) 上村他：大型屋外表示用 CRT 光源管, テレビ学技法, IDY'93167, Vol.17, No.71, pp.31-36, (Nov. 1993)

（受付日 1994年 9 月20日）

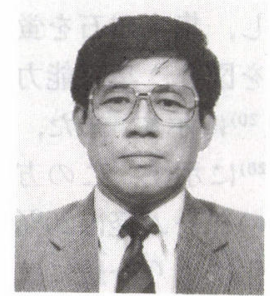

$\eta$ 現職.

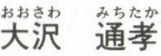

昭和 50 年、山形大学工学部電子工学科修 士課程終了, 铲日立製作所に入社, 映像メデ イア研究所に勤務し，CRT を用いた超高精 細直視, 投写型ディスプレイ, CRT 周辺シ ステムの研究開発に従事. 平成 6 年 8 月よ 